\title{
ATTITUDES AMONG CHEMISTRY TEACHERS TOWARDS INCREASING PERSONAL COMPETENCIES IN APPLYING ICT
}

\author{
POSTAWY NAUCZYCIELI CHEMII WOBEC ZWIĘKSZANIA \\ KOMPETENCJI OSOBISTYCH W STOSOWANIU PRAKTYKI TIK
}

\begin{abstract}
The study analyses opinions and attitudes among Chemistry teachers participating in the national project titled "Modernisation of the Educational Process in Primary and Secondary Schools". The research part of the study consists of the results of our findings examining the overall satisfaction of course participants with the professional level, difficulty, and contents of the designed TPACK-based (the Technological Pedagogical Content Knowledge) teaching model, as well as their self-assessment of the acquired skills and knowledge regarding the work with particular software and hardware applications. The results indicate that the course based on the TPACK framework and comprising specific examples of teaching activities supported by the use of technology was highly appreciated by teachers. Examples of methodologies for a suitable use of digital technologies in a particular curriculum topic in Chemistry, based on the TPACK model, were evaluated by teachers as the most beneficial ones, in terms of the actual teaching practice. The research confirmed that teachers expect to receive educational technologies together with high-quality methodical guidelines and particular examples of teaching activities involving appropriate and efficient use of the given digital technology in the teaching process.
\end{abstract}

Keywords: ICT in Chemistry teaching, teaching methods, educational technologies, courses for teachers, teaching Chemistry, Information and Communication Technologies

\section{Introduction}

Many studies have shown that the application of digital technologies in the teaching process increases the students' motivation and their interest in the curriculum and a given subject (see, for example [1-7]), and it also increases the level of understanding of the curriculum (see, for example [8-16]). On the other hand, efficient use of digital technologies in the teaching process remains to be a problem and a challenge the teachers are facing $[17,18]$, as they tend to perceive technology only as a tool for passing on the education contents and not as a tool for designing curricula with the aim to use technological experience to improve the teaching process $[19,20]$. Efficient integration of technologies into the teaching and learning process in a classroom is thus a rather demanding task for teachers [21] and a long-lasting process [22].

\footnotetext{
${ }^{1}$ Department of Didactics in Science, Psychology and Pedagogy, Faculty of Natural Sciences, Comenius University in Bratislava, Mlynská dolina, Ilkovičova 6, 84215 Bratislava, Slovakia, phone +421 260296601 , email: karolcik@fns.uniba.sk

*Corresponding author: karolcik@fns.uniba.sk
} 
Factors affecting the teachers' confidence in technologies include also the quantity and quality of available courses [23-25]. Intensity of using Information and Communication Technologies (ICT) by teachers is also affected by the contents and topics of the courses they undergo. Because good teaching is not simply adding technology to the existing teaching and content domain [26] courses should enable teachers acquire and extend their skills in using ICT [27], but cover also pedagogical aspects of using ICT in the teaching process [28].

With the aim to deal with the challenges related to the preparedness of teachers to efficiently integrate digital technologies into the teaching process, an important theoretical frame, the Technological Pedagogical Content Knowledge (TPACK), was created. The TPACK is not sufficient for the actual implementation of new technology in schools, but it is required that teachers have a positive attitude towards technologies [29, 30] and believe in their own ability to integrate new technologies in the teaching process, having thus strong self-efficacy beliefs [19, 29-31]. A teacher's self-efficacy was defined by Tschannen-Moran et al. [32] as "a teacher's belief in her or his ability to organize and execute the courses of action required to successfully accomplish a specific teaching task in a particular context". It is thus essential, when designing a model of professional development of teachers in the field of ICT implementation, to provide teachers with the opportunities not only to practice their technological skills, but also to understand the need to integrate the contents, methods, and technologies [33, 34] and develop a teacher's self-efficacy [19]. The research indicates that teachers' self-efficacy beliefs about using technology for teaching are directly related to their practice [35].

\section{Theoretical framework (TPACK)}

The study presents the course for teachers, focused on the technology integration into the teaching process, based on the TPACK model (for more information, see $[26,36]$ ). The TPACK was developed from the Shulman's concept of pedagogical content knowledge [37]. In the literature, we can also find the term TPCK, but both terms are acceptable [38].

TPACK is a pedagogy-oriented model, focused on the integration of technologies used by teachers, together with their pedagogical knowledge, into the teaching process [39].

The framework core consists of three components: a) content knowledge (CK) is teachers' knowledge about the subject matter to be learned or taught, b) pedagogical knowledge (PK) is teachers' deep knowledge about the processes and practices or methods of teaching and learning, and c) technological knowledge (TK) enables a person to accomplish a variety of different tasks using information technology and to develop different ways of accomplishing a given task [46]. Interconnecting and integration of these three basic components produces the pedagogical content knowledge (PCK), technological content knowledge (TCK), and technological pedagogical knowledge (TPK).

Pedagogical content knowledge (PCK) is in line with the Shulman's idea of pedagogy knowledge and includes the presentation of the content in interaction with pedagogical issues, such as selection of appropriate teaching approaches and methods. Technological content knowledge (TCK), as a combination of technologies and contents, relates to understanding of how technologies and contents influence and limit each other at the same time. Technological pedagogical knowledge (TPK) includes understanding of how various applications of technology may change teaching and learning [36, 39]. Interconnection and interactions of all these components create the TPACK framework (Fig. 1) that includes the knowledge and skills related to the technology as a part of the teaching process [26]. 
Hammond and Manfra [40] describe the TPACK as a method how technologies are integrated in the teaching process, and Koh and Chai [41] as the teachers' know-how for drawing upon their technological knowledge, pedagogical knowledge, and content knowledge to design Information and Communications Technology (ICT) lessons. The TPACK framework enables teachers to design pedagogical strategies and examine the changes required in the teachers' knowledge so that they are able to create efficient, technology-based teaching [19].

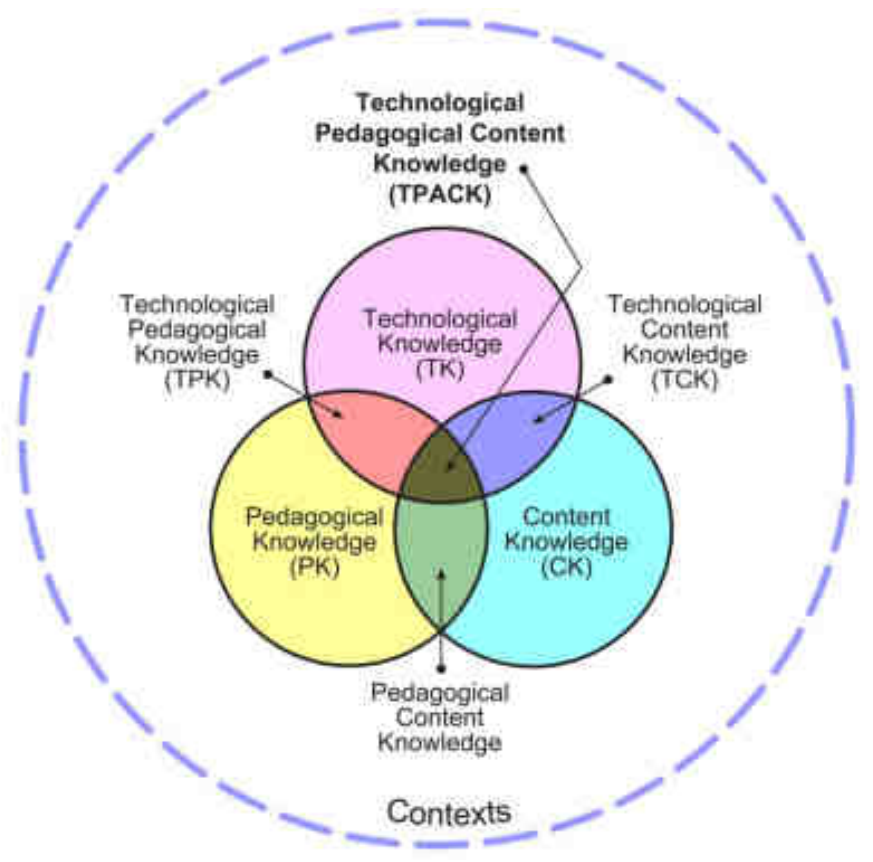

Fig. 1. TPACK Framework [39]

For the purpose of efficient technology integration, all three components (content, pedagogy, technology) must be in the dynamic equilibrium [26, 42] and change in one factor must be "compensated" by changes in other two factors. As an example of such dynamic equilibrium in the Chemistry teaching process, Mishra and Koehler [20] claim that teaching Chemistry (content) should be supported by visual representation of, for example, molecules (pedagogy), and by the technology facilitating the visualisation and manipulation. In this case, it is therefore appropriate to use the technology containing plugins enabling students view molecules dynamically and manipulate them. If the technology does not contain such tool, a teacher will be forced to use other methods of making the content available, which will affect pedagogy.

McCrory [43] believes that the precondition for the development of Science teachers covers four main knowledge bases. In addition to the content, technologies, and pedagogy, he adds also students. These four components should interact so that it is evident where in the curriculum to use technology, what technology to use, and how to teach with it. According to McCrory [43], teachers should possess adequate science knowledge to be able 
to help students understand the scientific concepts. They should also possess the knowledge of how students learn, which will enable them to develop strategies aimed at understanding scientific concepts also with regard to students' prior knowledge and misconceptions.

Niess [44] suggests a framework for the TPACK planning, based on four components: (1) an overarching concept about why the technology was incorporated into teaching a particular subject; (2) knowledge of students' understanding, thinking, and learning with technology in that subject; (3) knowledge of the curriculum; and (4) curriculum material in a particular subject that integrates technology into learning and teaching [44]. Jen et al. [45] believe that even though science teachers possess the knowledge of ICT tools and of how they will facilitate the teaching process, if they lack latest practical experience, their TPACK will not be developing; it is therefore necessary for teachers to learn how to use technology in practice in order to support teaching Science. Oster-Levinz and Klieger [46] emphasize that that guidance plays a significant role in the implementation of the integration of technological knowledge with the teachers' pedagogical content knowledge.

Other TPACK-based interpretations of the model and theoretical frameworks were created in the literature, such as Technological Learning Content Knowledge (TPLK), dealing with the use of technology in the teaching and learning process from the students point of view [47] the TPACK-practical, perceiving the teaching process as the basis upon which application knowledge (teaching experience) and TPACK skills work together [36, $48,49]$; the ICT-TPCK for the integration of tools and their affordances into the teaching process [50]; the TPCK-W for the integration of web technologies into pedagogical practice [51]; the TPACK-deep based on generic pedagogical strategies in terms of pedagogical and content knowledge [52] the teaching model titled TPACK Comprehension, Observation, Practice and Reflection (TPACK-COPR) [53]; the giving-prompting-making model, explicating the relationship between the PCK and the technology within the social studies classroom [40]; the Electronic Pedagogical Content Knowledge (ePCK), emphasizing pedagogical practices specific to the educational technology [54]; the Technological Pedagogical Science Knowledge (TPASK), intended for the professional development of Science teachers [55]; the ICT-Enhanced Teacher Development Model (ICTeTD), dealing not only with the knowledge base of the teaching process, but also with the development of teachers, and comprising all activities of a teacher of a particular subject, such as lesson planning, classroom instructions, evaluation, revaluation, and curriculum development [56], whereas this model was also applied to the professional development of Chemistry teachers [57].

The TPACK model was examined not only at the theoretical, but also the practical levels. Based on the literature reviewed, Chai et al. [47] identified four mutually dependent contextual factors, that might affect the lesson with the integrated TPACK, designed by teachers, in particular: a) intrapersonal dimension of context that refers to the epistemological and pedagogical beliefs that teachers hold; b) interpersonal dimension, especially in terms of designing a lesson together in a team; c) cultural/institutional factors, such as the prevalent view of seeing schools as cultural institutions and centre may exert strong influence on the use of technology, and d) physical/ technological provision. Guzey and Roehrig [58] observed that there is probably a relationship between the TPACK development among teachers and their pedagogical reasoning skills. In their study, they also found out that contextual constraints, such as availability of technology tools and characteristics of student population, had a strong impact on the TPACK development among teachers [58]. Polly et al. [18] emphasised that insufficient technical provision may 
cause that new teachers return to teaching without the use of technology. Results of the study by Jang and Tsai [59] showed that a teacher's TPACK is directly related to the amount of their teaching experience. Teaching experience and gender were also confirmed to be the factors affecting the TPACK among Science teachers from secondary schools by the following study [60]. The ways teachers think of and use technology to improve teaching Science may be significantly affected also by the structure and content of a given subject [49]. In their study, Koh and Chai [41] observed that teachers who were more confident in their pre-course TPACK deepened the correlation between their Content Knowledge and TPACK during the course. Teachers who were less confident in the TPACK perceived deeper correlation between their Pedagogical Content Knowledge and TPACK after the course. Therefore, initial differences in perceiving the TPACK observed among teachers produced differentiated effects on their perception of the TPACK development at the end of the course. The study carried out by Lin et al. [61] showed a positive effect of TK on the TPACK, TPK, and TCK, as well as a positive effect of TPK and TCK on the TPACK; therefore, in order to optimise the impact of these variables on teachers' TPACK, the authors recommend that the programmes aimed at developing the ICT skills among teachers adopt the strategies helping them develop their knowledge of technology and its application in the teaching process. So and Kim [21] examined the TPACK among pre-service teachers. The study results showed that pre-service teachers were able to understand pedagogical approaches of problem-based learning and what technology integration meant to them for teaching and learning (espoused TPCK), but had difficulties applying their beliefs and knowledge into designing pedagogically-sound technology-integrated lessons (in use TPCK).

Efficient use of technologies in teaching Science and Chemistry, with regard to the TPACK framework, was studied by several researchers (see, for example [19, 58, 59, 62-67].

\section{Research design}

The objective of the research was to identify the attitudes held by Chemistry teachers with regard to improving their competencies in the field of ICT applications. Teachers' attitudes were examined using the questionnaires. The research was carried out in the period of three years (2011-2013), using electronic questionnaires available on-line, filled out by respondents after the course completion.

The questionnaire had a specific structure and contained in total 18 questions; out of these, 12 scaled items examined the degree of satisfaction among the course participants with the course execution and contents and 3 items examined the changes in the teachers' knowledge and competences before and after the course, in terms of skills in using the key ICT. Other 3 items were open and focused on the evaluation of the coursebook for teachers, created especially for the course. Reliability of the questionnaire, calculated using the Cronbach's $\alpha$ parameter, showed a still acceptable value of 0.68 .

For the purpose of research execution, we formulated three main inquiry questions:

1. How do Chemistry teachers evaluate the course agenda, process, and execution?

2. Which of the presented digital technologies are regarded by Chemistry teachers as the most usable in the actual teaching practice?

3. Which part of the course is regarded by Chemistry teachers as the most beneficial, in terms of actual teaching practice? 
4. How do Chemistry teachers evaluate their own competences regarding the integration of the presented technologies into Chemistry teaching?

\section{Participants}

The research was carried out with the group of 323 Chemistry teachers. They were qualified teachers with various durations of their pedagogical experience, working in schools in various regions of Slovakia. All teachers demonstrated an adequate level of knowledge and experience and ability to present their statements regarding appropriate and methodically well-prepared application of digital technologies to the teaching process.

\section{Course description}

The course for Chemistry teachers was carried out within the national project titled Modernisation of the Educational Process in Primary and Secondary Schools, co-financed from the EU resources and carried out in training centres in Slovakia within the period of 2008-2013. The main objective of the project was the innovation and modernisation of teaching procedures, methods, and forms of education, supported by appropriate and didactically well-prepared application of available digital technologies [40]. Within the national project, 6670 participants completed the course - teachers of various subjects, such as Biology, Chemistry, Physics, Mathematics, Art, Music, History, etc. From which 4898 participants have participated in our research.

The course as such was preceded by the preparation stage, during which a group of experts, consisting mainly of Chemistry teachers, methodologists, and experts in didactics with long-lasting experience with the utilisation of digital technologies in the teaching process, prepared the coursebooks and guidance methodical materials. They were mainly methodically well-prepared manuals for the work with selected technologies, lesson models, and suggestions for appropriate selection of a selected digital teaching aid for the Chemistry teaching. Experts also compiled a detailed course agenda and schedule. During this stage, in addition to the coursebook preparation, the national network of training centres was built and instructors were trained.

The course was divided into three modules and comprised the presentation and distance (e-learning) forms of education. In the beginning of the course, each participant received a laptop to be used not only during the course, but also at work, within the preparation of their lessons.

\section{Module 1}

As the project included more than 6,600 participants teaching various subjects, the main objective of the first module of the course was to achieve approximately the same level of general digital literacy among all teachers participating in the project. The objectives of this module were focused on the acquisition of technological knowledge (TK), i.e. how to use selected hardware and software (Table 1). During the course, teachers were given the opportunity to become more familiar with the laptop they were given, with the installed package of software applications, and for the project purposes, also with the launched e-learning environment. The core of the course activities within this module consisted of assignments aimed at identification of the achieved level of skills in work with electronic documents in the MS Office software. The course agenda was supplemented with available tools of electronic mail and on-line communication (chat, videoconference, etc.). 
Module 1 content

\begin{tabular}{|c|c|c|c|}
\hline Component & Hardware & Software & On-line \\
\hline \multirow{5}{*}{ TK } & Laptop & Operating system & e-mail \\
\cline { 2 - 4 } & & LMS & Wikis \\
\cline { 2 - 4 } & & MS Word & Internet sites \\
\cline { 2 - 4 } & & MS Excel & videoconference \\
\cline { 2 - 4 } & & MS PowerPoint & \\
\cline { 2 - 4 } & & e-mail & \\
\cline { 2 - 4 } & & videoconference & \\
\hline
\end{tabular}

The extent of training within this module depended on the achieved skills in work with ICT. If teachers assessed their own skills as intermediate, they completed the course in the extent of 12 lessons in the presentation form. The presentation form of education for the teachers with advanced skills was reduced to 6 lessons (Table 2).

Number of lessons in individual course modules

Table 2

\begin{tabular}{|l|c|c|c|}
\cline { 2 - 4 } \multicolumn{1}{c|}{} & Module 1 & Module 2 & Module 3 \\
\hline Presentation form & $12^{*}$ & 18 & 30 \\
\hline Distance form & 6 & 6 & $34^{* *}$ \\
\hline Total for module & 18 & 24 & 64 \\
\hline
\end{tabular}

${ }^{*}$ intermediate, ${ }^{* *}$ out of this number, 10 lessons for the final assignment

\section{Module 2}

The content of Module 2 consisted of the contemporary didactic technology in a teacher's work (Table 3). The extent of training within this module was 18 lessons in the presentation form of education and 6 lessons in form of distance education (Table 2). During the course, Chemistry teachers had the opportunity to become familiar with the selected technologies usable in the process of teaching Science (TK). They acquired the information in the field of initial processing and publishing a digital image, sound, video, installation and functional interconnection of peripherals, they tried to work with an interactive board, tablet, and a voting system. Chemistry teachers also paid attention to technologies facilitating the exploration of the surrounding environment by students, using a digital microscope and a computer-based laboratory $(\mathrm{COACH}$, Vernier). Within the discussions, together with the instructor they suggested examples of using the given technologies in Chemistry teaching (TCK). Teachers also became familiar with new teaching approaches, forms of education, and organising the teaching process while using selected digital technologies. In all performed teaching activities, the emphasis was put on methodically appropriate, premeditated, and meaningful implementation of the presented technologies in the teaching process (TPK).

In Module 2, teachers were asked to create several scenarios, in which their presented their strategies how to apply a selected technology. They demonstrated to be ready to use digital technologies by practical connecting, installation, calibration, launch, and control of a selected equipment (device), or by testing the functionality of the recommended software applications [68]. 
Module 2 Content

\begin{tabular}{|c|c|c|}
\hline TK & TPK & TCK \\
\hline Social networks & & $\begin{array}{l}\text { Examples of using social networks } \\
\text { in teachers' work }\end{array}$ \\
\hline Digital microscope & $\begin{array}{l}\text { Collaborative teaching using } \\
\text { a digital microscope }\end{array}$ & $\begin{array}{l}\text { Examples of using a digital } \\
\text { microscope in Chemistry teaching } \\
\text { (e.g. salt crystallisation) }\end{array}$ \\
\hline Microcomputer-based laboratory & MBL-based inquiry learning & $\begin{array}{l}\text { Examples of using the MBL in } \\
\text { Chemistry teaching (e.g. } \\
\text { potentiometric determination of } \mathrm{pH})\end{array}$ \\
\hline $\begin{array}{c}\text { Interactive board and applications } \\
\text { supplied with interactive boards } \\
\text { (ActivStudio, Flow!Works, SMART } \\
\text { Notebook) }\end{array}$ & $\begin{array}{l}\text { Interactive board as a tool supporting } \\
\text { the personalisation of teaching, } \\
\text { collaborative teaching, motivation } \\
\text { and increasing involvement of } \\
\text { students }\end{array}$ & $\begin{array}{l}\text { Examples of using an interactive } \\
\text { board in Chemistry teaching }\end{array}$ \\
\hline E-voting & $\begin{array}{l}\text { Increasing involvement of students } \\
\text { using the e-voting, strengthening the } \\
\text { summary evaluation and feedback }\end{array}$ & $\begin{array}{l}\text { Examples of using the e-voting in } \\
\text { Chemistry teaching }\end{array}$ \\
\hline Visualiser & $\begin{array}{c}\begin{array}{c}\text { Support of visualisation and } \\
\text { modelling }\end{array} \\
\end{array}$ & $\begin{array}{l}\text { Examples of using a visualiser in } \\
\text { Chemistry teaching }\end{array}$ \\
\hline $\begin{array}{c}\text { Digital camera and processing } \\
\text { of a digital video }\end{array}$ & $\begin{array}{l}\text { Support of visualisation, use of } \\
\text { experiments in the teaching process }\end{array}$ & $\begin{array}{l}\text { Examples of using a video (video } \\
\text { experiments) in Chemistry teaching }\end{array}$ \\
\hline
\end{tabular}

\section{Module 3}

A key course module was Module 3, covering 64 lessons (Table 2). In terms of the profile of a course participant, as an expert in application of available digital technologies to Chemistry teaching.

With regard to the TPACK framework, this module was focused on the acquisition and interconnection of the knowledge from all three areas - technology, pedagogy, and content. The list of topics within Module 3, included in the TPACK framework, is shown in Figure 2.

\section{The TPACK framework - Chemistry topics in course agenda}

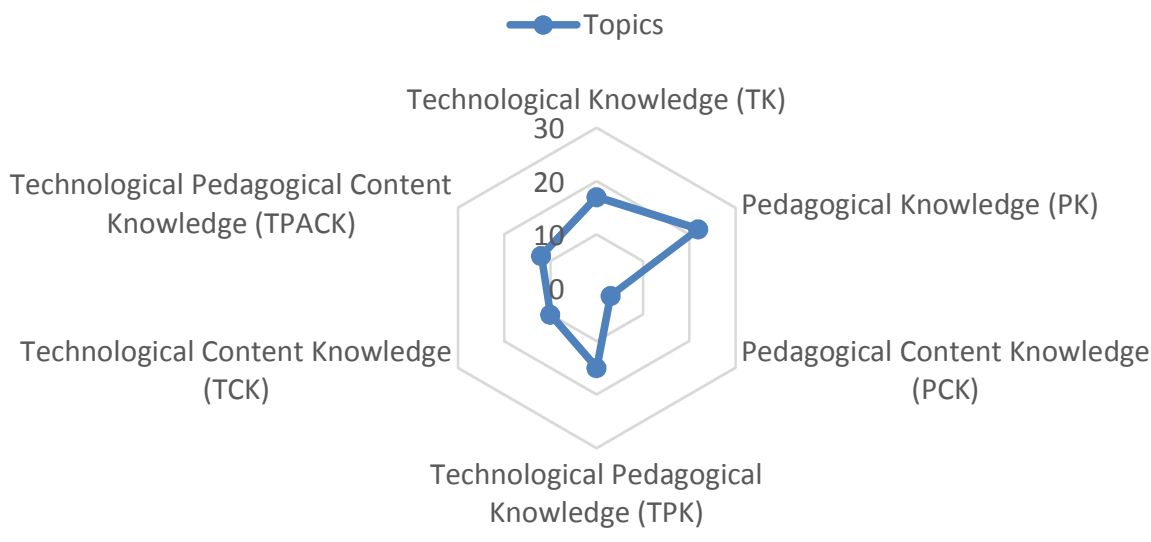

Fig. 2. Chemistry topics in course agenda in terms of TPACK 
The course agenda consisted of two topic areas. The first area (Part 1 of Module 3) was dominated by more general topics regarding the transformation of schools and classrooms in the society, where digital technologies take over a key role when dealing with common real-life situations. Teachers were discussing the extent of required systemic changes in their work, new educational concepts (PK), inspiring ideas of eminent education reformers (PK), didactic means and transformation (digitalisation) of teaching aids (TK). They were also dealing with technological innovations, developmental trends, as well as possible applications of selected forms of teaching organisation and progressive teaching methods that bring interesting education results, from the pedagogical research point of view (TK, TPK, TCK, TPACK).

The second topic area (Part 2 of Module 3), studied by Chemistry teachers within Module 3, was focused mainly on specific features of the application of digital technologies to the Chemistry subject, while using also the knowledge acquired in Modules 1 and 2 (Table 4). The group of experts designed the course agenda while considering also the development of dominant key competences of a student in a given subject, also with regard to the Recommendation of the European Parliament and of the Council on Key Competences for Lifelong Learning [69], or the ISTE Standards [70]. The experience gained by the specialists with the implementation of digital technologies in teaching Chemistry in common conditions in Slovakia was taken into consideration as well, together with the experience of researchers in the field of implementation of technology in teaching Science (e.g. [63, 71-76]). For this purpose, the group of experts prepared the examples of lesson models that included the application of available software products in the teaching process (based on the TPACK). In addition to the MS Office, software for microcomputer-based laboratory (Vernier, Coach), and interactive boards (ActivStudio, Flow!Works, SMART Notebook), representing the content, teachers also became familiar with software solutions designed specifically for Chemistry. These were mainly freely accessible, freely distributable, so-called open-source software products. Chemistry teachers have thus become more familiar with the work in the software environment particularly intended for drawing chemical structures and chemical equipment ACD/ChemSketch, modelling and simulation of various processes in Chemistry (YENKA, Virtual Lab Simulation), selected software products facilitating creation of quizzes and games (EclipseCrossword, Jigs@wPuzzle and Jigsaw Puzzle Lite, Periodic Table Classic), as well as the comprehensive educational environment with an extensive database of educational objects - The Knowledge Planet. In addition to the basic description of technical parameters of a particular software solution, recommended installation procedures, and brief characteristics of the key control tools and components, Chemistry teachers were trained with the emphasis being put on efficient and meaningful use of a software product in the teaching process in a particular school. A critical, and, above all, professionally qualified attitude towards the level of appropriate use of a particular technological platform was expected from Chemistry teachers with regard to all software solutions that were made available to them.

An example of preparing a teaching activity focused on the use of MBL in the inquiry-based Chemistry instruction, with regard to the TPACK framework, is shown Figure 3. Upon completion of all agendas of individual modules, Chemistry teachers had the opportunity to acquire the competencies of how to integrate technology efficiently and meaningfully into their own teaching, so that individual TPACK components are balanced and the teaching brings good results. 
Module 3 Content

\begin{tabular}{|c|c|c|c|c|c|}
\hline TK & PK & PCK & TPK & TCK & TPACK \\
\hline $\begin{array}{l}\text { MBL (in } \\
\text { Module 2) }\end{array}$ & $\begin{array}{l}\text { Inquiry-based } \\
\text { learning }\end{array}$ & $\begin{array}{c}\text { Inquiry-based } \\
\text { conceptual } \\
\text { Chemistry } \\
\text { learning } \\
\end{array}$ & $\begin{array}{c}\text { MBL based } \\
\text { inquiry learning }\end{array}$ & $\begin{array}{l}\text { MBL transformed } \\
\text { Chemistry } \\
\text { concepts (in } \\
\text { Module 2) } \\
\end{array}$ & $\begin{array}{l}\text { Methods how to use MBL } \\
\text { as the tool to improve IBSE } \\
\text { in Chemistry teaching, e.g. } \\
\text { topics of Conductivity, pH }\end{array}$ \\
\hline $\begin{array}{l}\text { MS Office, } \\
\quad \text { digital } \\
\text { camera (in } \\
\text { Modules } 1 \\
\text { and 2) }\end{array}$ & $\begin{array}{l}\text { Project-based } \\
\text { learning }\end{array}$ & $\begin{array}{c}\text { Teaching } \\
\text { chemical } \\
\text { concepts } \\
\text { through project- } \\
\text { based learning }\end{array}$ & $\begin{array}{l}\text { MS Office, } \\
\text { digital camera } \\
\text { and a video } \\
\text { camera as } \\
\text { a cognitive tool }\end{array}$ & $\begin{array}{l}\text { MS Office and } \\
\text { digital camera } \\
\text { transformed } \\
\text { Chemistry } \\
\text { concepts (in } \\
\text { Module 2) } \\
\end{array}$ & $\begin{array}{c}\text { Methods how to use } \\
\text { technology as a tool to } \\
\text { improve project-based } \\
\text { learning in Chemistry, e.g. } \\
\text { topic of Water, Chemistry } \\
\text { around us } \\
\end{array}$ \\
\hline $\begin{array}{c}\text { LMS (in } \\
\text { Module 1) }\end{array}$ & $\begin{array}{l}\text { Blended } \\
\text { learning }\end{array}$ & $\begin{array}{l}\text { Blended } \\
\text { learning in } \\
\text { Chemistry } \\
\text { teaching }\end{array}$ & $\begin{array}{l}\text { LMS in blended } \\
\text { Science learning }\end{array}$ & $\begin{array}{l}\text { The Knowledge } \\
\text { Planet learning } \\
\text { environment }\end{array}$ & $\begin{array}{l}\text { Methods how to use the } \\
\text { Knowledge Planet as a tool } \\
\text { to improve the blended } \\
\text { learning in Chemistry, e.g. } \\
\text { topic of Chemical Bond }\end{array}$ \\
\hline $\begin{array}{l}\text { LMS (in } \\
\text { Module 1) }\end{array}$ & Visualisation & $\begin{array}{l}\text { Visualisation } \\
\text { and } \\
\text { understanding } \\
\text { of abstract } \\
\text { chemical } \\
\text { concepts } \\
\end{array}$ & $\begin{array}{l}\text { Visualisation } \\
\text { through } \\
\text { simulation and } \\
\text { modelling } \\
\text { (digital objects) }\end{array}$ & $\begin{array}{l}\text { The Knowledge } \\
\text { Planet learning } \\
\text { environment }\end{array}$ & $\begin{array}{l}\text { Methods how to use the } \\
\text { Knowledge Planet as a tool } \\
\text { for visualisation and } \\
\text { understanding of abstract } \\
\text { chemical concepts, e.g. } \\
\text { Chemical Bond topic }\end{array}$ \\
\hline $\begin{array}{l}\text { ACD/Chem- } \\
\text { Sketch }\end{array}$ & Visualisation & $\begin{array}{l}\text { Visualisation } \\
\text { and } \\
\text { understanding } \\
\text { of abstract } \\
\text { chemical } \\
\text { concepts }\end{array}$ & $\begin{array}{l}\text { Visualisation } \\
\text { through } \\
\text { modelling }\end{array}$ & $\begin{array}{l}\text { Chemsketch as } \\
\text { a tool for better } \\
\text { understanding of } \\
\text { Chemistry, } \\
\text { especially the } \\
\text { molecular } \\
\text { structure } \\
\end{array}$ & $\begin{array}{l}\text { Methods how to use } \\
\text { Chemsketch as a tool to } \\
\text { improve visualisation } \\
\text { a understanding of abstract } \\
\text { chemical concepts, e.g. } \\
\text { Hybridisation topic }\end{array}$ \\
\hline \\
\hline \multicolumn{6}{|l|}{ ISIS/Draw } \\
\hline $\begin{array}{c}\text { Interactive } \\
\text { board (in } \\
\text { Module 1), } \\
\text { EclipseCross } \\
\text { word/ } \\
\text { Jigs@wPuzz- } \\
\text { le/Jigsaw } \\
\text { Puzzle Lite } \\
\end{array}$ & $\begin{array}{l}\text { Activating } \\
\text { teaching } \\
\text { methods (e.g. } \\
\text { didactic } \\
\text { games, } \\
\text { brainstorming, } \\
\text { brainmap) }\end{array}$ & $\begin{array}{l}\text { Benefit of } \\
\text { activating } \\
\text { methods for } \\
\text { Chemistry } \\
\text { teaching }\end{array}$ & $\begin{array}{l}\text { IWB-based } \\
\text { student } \\
\text { activities }\end{array}$ & $\begin{array}{l}\text { IWB as a mean to } \\
\text { make chemical } \\
\text { content accessible } \\
\text { (in Module 2) }\end{array}$ & $\begin{array}{l}\text { Methods how to use IWB, } \\
\text { software for IWB and } \\
\text { Puzzle to increase } \\
\text { involvement of students, } \\
\text { e.g. Enzymatic Reactions } \\
\text { topic }\end{array}$ \\
\hline $\begin{array}{c}\text { Digital } \\
\text { camera } \\
\text { (Module 2) }\end{array}$ & $\begin{array}{c}\text { Conceptual } \\
\text { learning and } \\
\text { understanding }\end{array}$ & $\begin{array}{l}\text { Conceptual } \\
\text { Chemistry } \\
\text { learning }\end{array}$ & $\begin{array}{l}\text { Video based } \\
\text { conceptual } \\
\text { learning }\end{array}$ & $\begin{array}{l}\text { Video as a mean } \\
\text { to make chemical } \\
\text { experiments } \\
\text { accessible (in } \\
\text { Module 2) }\end{array}$ & $\begin{array}{l}\text { Methods how to use video } \\
\text { experiments to improve } \\
\text { student conceptual learning } \\
\text { and understanding, e.g. } \\
\text { video experiments, such } \\
\text { as Dichromate Volcano, } \\
\text { Fire from Water } \\
\end{array}$ \\
\hline Yenka & $\begin{array}{c}\text { Conceptual } \\
\text { learning and } \\
\text { understanding }\end{array}$ & $\begin{array}{l}\text { Conceptual } \\
\text { Chemistry } \\
\text { learning }\end{array}$ & $\begin{array}{l}\text { Virtual } \\
\text { experiment } \\
\text { based } \\
\text { conceptual } \\
\text { learning }\end{array}$ & $\begin{array}{l}\text { Yenka as a tool for } \\
\text { virtual } \\
\text { experiments and } \\
\text { modelling in } \\
\text { Chemistry }\end{array}$ & $\begin{array}{c}\text { Methods how to use virtual } \\
\text { experiments and modelling } \\
\text { to improve student } \\
\text { conceptual learning and } \\
\text { understanding, e.g. } \\
\text { Chemical Reaction Rate }\end{array}$ \\
\hline $\begin{array}{l}\text { Virtual Lab } \\
\text { Simulation }\end{array}$ & & & & & \\
\hline
\end{tabular}




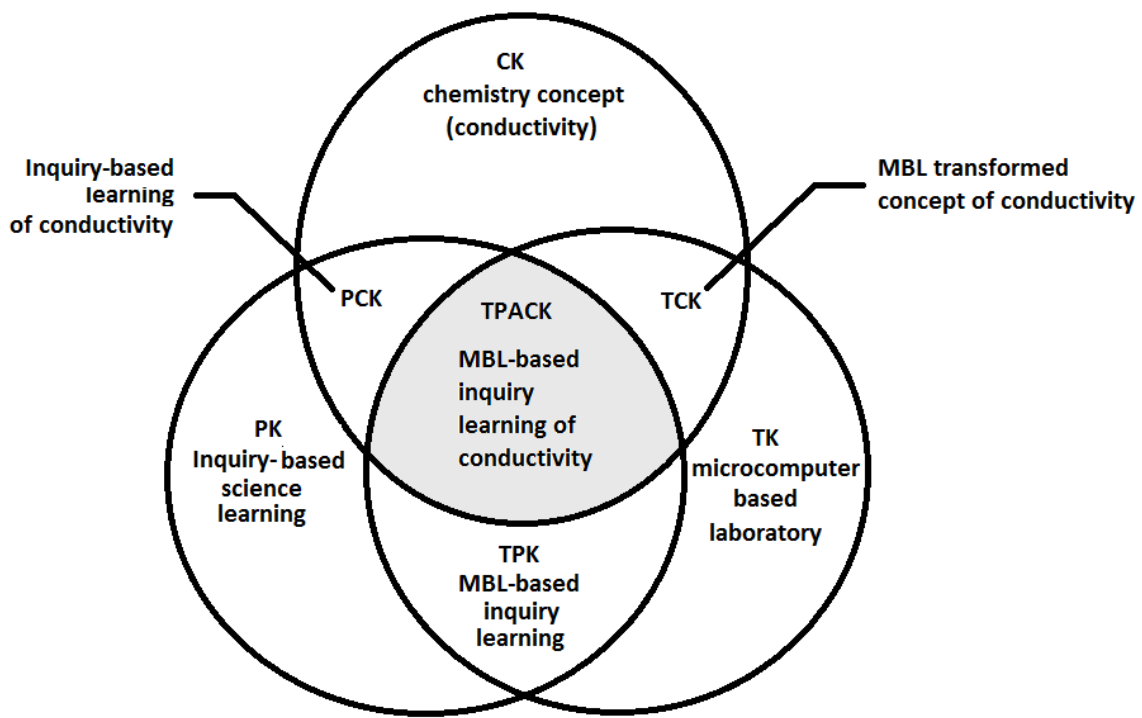

Fig. 3. Example of MBL Integration into the inquiry-based chemistry instruction

Contents of individual course agendas were slightly different, depending on the level and type of schools where the Chemistry teachers work. Differences were in the offered methodologies, selected chemical problems and topics, as well as the extent of appropriate inclusion of digital teaching aids in model lessons.

Teachers were inspired by detailed scenarios of lesson models, supplemented with a large amount of original teaching aids, interactive worksheets, electronic exercises, and methodical manuals how to work with particular software, so that the application thereof brings the best learning results. Elaborated methodologies are constantly available to Chemistry teachers via the project's digital library.

\section{Results and discussion}

In the following analysis, we will concentrate only on the observed results of the questionnaire-based inquiry, related to the evaluation by and opinions of Chemistry teachers with regard to Module 3, focused on the efficient integration of technology into Chemistry teaching.

\section{Results of evaluation of the completed agenda in Module 3}

Most frequent comments provided by course participants with regard to Module 3 were related to the organisation of trainings, especially to the locations of assigned training centres and their technical equipment. The comments also concerned the lack of time for practicing the acquired skills in work with selected technologies, missing coursebooks, and ability to discuss their application to teaching Chemistry. However, majority of participants expressed their extraordinary satisfaction with Module 3 (Table 5).

The designed agenda of the course for Chemistry teachers in Module 3 was mainly focused on the development of personal competencies among teachers, regarding the integration of technology into Chemistry teaching, based on the TPACK theoretical 
framework, as well as designing their own lessons, while considering the meaningful use of digital technologies.

Table 5

Evaluation of the content of Module 3 within the course (323 Chemistry teachers, compared to 4,898 all trained teachers)

\begin{tabular}{|c|c|c|c|c|c|c|c|c|}
\hline & $\begin{array}{c}\text { Frequency } \\
\text { Chem }\end{array}$ & $\begin{array}{c}\text { Frequency } \\
\text { All }\end{array}$ & $\begin{array}{c}\text { Percent } \\
\text { Chem }\end{array}$ & $\begin{array}{c}\text { Percent } \\
\text { All }\end{array}$ & $\begin{array}{c}\text { Valid } \\
\text { Percent } \\
\text { Chem }\end{array}$ & $\begin{array}{c}\text { Valid } \\
\text { Percent } \\
\text { All }\end{array}$ & $\begin{array}{c}\text { Cumulative } \\
\text { Percent } \\
\text { Chem }\end{array}$ & $\begin{array}{c}\text { Cumulative } \\
\text { Percent All }\end{array}$ \\
\hline Excellent & 113 & 2,167 & 35 & 44.2 & 35 & 44.2 & 35 & 44.2 \\
\hline Good & 179 & 2,280 & 55.4 & 46.5 & 55.4 & 46.5 & 90.4 & 90.8 \\
\hline Satisfactory & 30 & 409 & 9.3 & 8.4 & 9.3 & 8.4 & 99.7 & 99.1 \\
\hline $\begin{array}{c}\text { More } \\
\text { unsatisfactory }\end{array}$ & 1 & 38 & 0.3 & 0.8 & 0.3 & 0.8 & 100 & 99.9 \\
\hline Unsatisfactory & 0 & 4 & 0 & 0.1 & 0 & 0.1 & & 100 \\
\hline Total & 323 & 4,898 & 100 & 100 & 100 & 100 & & \\
\hline
\end{tabular}

Table 6

Evaluation of answers provided by all participants and by Chemistry Teaching Participants to the question: How useful is "Part 1 of Module 3" for more comprehensive understanding of the issues related to education modernisation supported by digital technologies?

\begin{tabular}{|c|c|c|c|c|c|c|c|c|}
\hline & $\begin{array}{c}\text { Frequency } \\
\text { Chemistry }\end{array}$ & $\begin{array}{c}\text { Frequency } \\
\text { All }\end{array}$ & $\begin{array}{c}\text { Percent } \\
\text { Chemistry }\end{array}$ & $\begin{array}{c}\text { Percent } \\
\text { All }\end{array}$ & $\begin{array}{c}\text { Valid } \\
\text { Percent } \\
\text { Chemistry }\end{array}$ & $\begin{array}{c}\text { Valid } \\
\text { Percent } \\
\text { All }\end{array}$ & $\begin{array}{c}\text { Cumulative } \\
\text { Percent } \\
\text { Chemistry }\end{array}$ & $\begin{array}{c}\text { Cumulative } \\
\text { Percent All }\end{array}$ \\
\hline $\begin{array}{c}\text { Very } \\
\text { useful }\end{array}$ & 173 & 2,849 & 53.6 & 58.2 & 53.6 & 58.2 & 53.6 & 58.2 \\
\hline $\begin{array}{c}\text { Partially } \\
\text { useful }\end{array}$ & 103 & 1,365 & 31.9 & 27.9 & 31.9 & 27.9 & 85.4 & 86 \\
\hline $\begin{array}{c}\text { More } \\
\text { useful } \\
\text { than } \\
\text { unuseful }\end{array}$ & 38 & 576 & 11.8 & 11.8 & 11.8 & 11.8 & 97.2 & 97.8 \\
\hline $\begin{array}{c}\text { Little } \\
\text { useful }\end{array}$ & 8 & 96 & 2.5 & 2 & 2.5 & 2 & 99.7 & 99.8 \\
\hline Unuseful & 1 & 12 & 0.3 & 0.2 & 0.3 & 0.2 & 100 & 100 \\
\hline Total & 323 & 4,898 & 100 & 100 & 100 & 100 & & \\
\hline
\end{tabular}

Teachers appreciated the most the fact that the course content was focused on possible applications of digital technology in the Chemistry subject and that the acquired knowledge may be instantly applied to their teaching practice. Research confirmed that opinions regarding the content of Module 3 (Table 5) among the Chemistry teacher participants are similar to the opinions of majority of participants on this issue. As much as $90.4 \%$ of teachers who completed Module 3 in the Chemistry subject evaluated the overall quality of the course as good (55.4\%) or high (35\%). The first part of Module 3, focused on the generalising information and innovative approaches to education modernisation supported by digital technologies (Table 6), is regarded as very useful by more than a half $(53.6 \%)$ of Chemistry teaching participants. The findings regarding the evaluation of the overall level of the course in Module 3 were also very pleasing, as more than one third $(40.6 \%)$ of Chemistry teachers evaluated it as excellent and $48.9 \%$ as good. In the context of high requirements of the course, with regard to its content, extent, and required skills $(72.8 \%$ of Chemistry teaching participants evaluated the difficulty of Module 3 as high or rather high), 
these results are encouraging, indicating that Chemistry teachers are able to appreciate even a course with very high expertise requirements, provided that they regard the course focus and contents as meaningful and beneficial for their pedagogical activities.

Similarly, in case of Chemistry teaching participants, on average, extraordinarily high values were confirmed for the quality of instructors' work. As much as $66.9 \%$ of Chemistry teachers (Table 7) evaluated the instructor's quality as the best, i.e. high-quality. Instructor's expertise, preparedness degree, as well as the overall approach to their obligations, were assessed as good by other $27.9 \%$. In total, almost $96 \%$ of course participants who teach Chemistry expressed their high satisfaction with the instructor's work and professional approach. With regard to the aforesaid, it is necessary to emphasize that instructors had to undergo a three-week special training and applicants were chosen from among innovative Chemistry teachers with prior experience with the application of digital technologies in the teaching process. We can assume that particularly this fact has a strong impact on their collegial approach and their frequently appreciated ability to understand specific problems (technical equipment in schools, education organisation, etc.) that are directly related to the application of technologies and innovative approaches in the teaching process.

Table 7

Evaluation of answers provided by all participants and by the Participants Teaching Chemistry to the question: State how you assess the instructor's quality (expertise, preparedness, approach)

\begin{tabular}{|c|c|c|c|c|c|c|c|c|}
\hline & $\begin{array}{c}\text { Frequency } \\
\text { Chemistry }\end{array}$ & $\begin{array}{c}\text { Frequency } \\
\text { All }\end{array}$ & $\begin{array}{c}\text { Percent } \\
\text { Chemistry }\end{array}$ & $\begin{array}{c}\text { Percent } \\
\text { All }\end{array}$ & $\begin{array}{c}\text { Valid } \\
\text { Percent } \\
\text { Chemistry }\end{array}$ & $\begin{array}{c}\text { Valid } \\
\text { Percent } \\
\text { All }\end{array}$ & $\begin{array}{c}\text { Cumulative } \\
\text { Percent } \\
\text { Chemistry }\end{array}$ & $\begin{array}{c}\text { Cumulative } \\
\text { Percent All }\end{array}$ \\
\hline High & 216 & 3,651 & 66.9 & 74.5 & 66.9 & 74.5 & 66.6 & 74.5 \\
\hline Good & 90 & 1,046 & 27.9 & 21.4 & 27.9 & 21.4 & 94.7 & 95.9 \\
\hline Satisfactory & 16 & 179 & 5 & 3.7 & 5 & 3.7 & 99.7 & 99.6 \\
\hline $\begin{array}{c}\text { Little } \\
\text { satisfactory }\end{array}$ & 1 & 17 & 0.3 & 0.3 & 0.3 & 0.3 & 100 & 99.9 \\
\hline Unsatisfactory & 0 & 5 & 0 & 0.1 & 0 & 0.1 & & 100 \\
\hline Total & 323 & 4,898 & 100 & 100 & 100 & 100 & & \\
\hline
\end{tabular}

\section{Results of increasing the competences of teachers in particular ICT applications for education}

A limited extent of this article does not allow for more detailed analyses of all software and hardware environments, equipment, and digital teaching aids that the Chemistry teachers became familiar with during the Module 3. Therefore, our evaluation only covers the applications representing the basis of the agenda of the course for Chemistry teachers in this Module and is supplemented with the opinions of participants on the importance and benefit of the prepared methodologies in lesson models created by the team of experts.

\section{ACD/ChemSketch [77]}

In the basic version, it is a freely accessible software application intended for desktop computers (PC or MAC). However, downloading requires the registration at the website of the company producing this software. The ChemSketch is a full-value tool for the work with the Chemistry content, suitable for building chemical formulas, 3D representation thereof, as well as visualisation of chemical equipment. Working in a software environment requires certain amount of abstraction, spatial perception, and chemical theory; it is 
therefore more suitable for teachers or older students. They may use it to construct a structure of a chemical compound in various isomers. For younger students, representations of chemical equipment are more suitable. A great benefit of the ChemSketch product is the availability of a wide database, constantly updated, which may motivate students to further inquiry.

Prior to the completion of the course, the level of teachers' knowledge and skills for the work with the Chemistry graphical software was evaluated by $58.8 \%$ of Chemistry teachers as very low, whereas almost $44.6 \%$ of them have never encountered the ChemSketch application prior to the course. Only $0.3 \%$ of teachers evaluated their skills in work with this software as excellent.

After the course, the situation radically changed and $54.7 \%$ of Chemistry teachers assessed themselves as users of the ChemSketch chemical graphics software with excellent or very good skills and competences. According to the results of the statistical analysis (Table 8), we disproved the hypothesis on equality of the measured means and confirmed that the differences in the evaluation of skills and competences of participants before and after the course were not accidental and can be explained by the success of the course agenda.

Moreover, $23.6 \%$ of Chemistry teachers stated that the ChemSketch is the best usable educational software application in the real teaching practice.

\section{Software products for the creation of interactive tasks with multimedia content and e-learning educational environment}

The first group of software products consists of freely downloadable simple software applications for the fast creation of crossword puzzles, word search games, and pictures in form of a puzzle that may be used especially at Chemistry lessons in primary schools. Software solutions within the Module 3 agenda of the course for Chemistry teachers included the products such as EclipseCrossword, Jigs@wPuzzle, and Jigsaw Puzzle Lite. E-learning systems (LMS), facilitating distance forms of learning, represented the second group of technologies that the course participants were becoming familiar with.

Prior to the course, $44.5 \%$ of Chemistry teachers assessed the level of their knowledge and skills in the work with software for the creation of interactive tasks using the e-learning environments as very low, while almost one third of them, $30.3 \%$, had no prior experience with such software products. Only $0.6 \%$ of teachers assessed their skills in the work with such software as excellent.

After the course, the situation improved and almost 3/4 (74.5\%) of Chemistry teachers assessed themselves as users with excellent or very good skills and competences. On the basis of statistical verification (Table 8), also in this case we had to disprove the hypothesis on the equality of measured means and confirm that the differences in the evaluation of skills and competences of course participants before and after the course were not accidental and can be explained by the success of the course agenda. As for the usability of educational technologies in the real teaching practice, $9.3 \%$ of teachers stated that the software products for the creation of interactive tasks were the aids with the highest usability.

\section{Work with interactive whiteboards}

There are several types of interactive whiteboards from various manufacturers (QOMO, ACTIVboard, SMARTboard, Interwrite board), each using their own software. 
Examples and methodically prepared samples of using interactive whiteboards in Chemistry teaching were created in the ActivStudio software.

While with regard to the ChemSketch software application almost one half of Chemistry teachers stated that before the course they had no knowledge of the application, $29.1 \%$ of course participants were not aware of interactive whiteboards at all before Module 3, and only ten (3.1\%) teachers assessed their knowledge and skills in work with this software as excellent. After the course, this proportion significantly changed in favour of Chemistry teachers, who assessed their knowledge and skills in work with interactive whiteboards as excellent. This category subsequently consisted of more than one fifth (22\%) of all participants teaching Chemistry.

Also in case of work with interactive whiteboards, on the basis of statistical verification (Table 8), the hypothesis on equality of measured medians was disproved and it was confirmed that the differences in the evaluation of skills and competences of course participants before and after the course were not accidental and may be explained by the success of the course agenda.

In the open question, $7.5 \%$ of Chemistry teachers assessed the examples of using interactive whiteboards in Chemistry teaching as the aids with the highest usability in the real teaching practice.

Table 8

Paired $t$-test values calculated for the questions comparing the levels of acquired knowledge and skills among course participants before and after the course, by individual software applications

\begin{tabular}{|c|c|c|c|c|c|c|c|c|}
\hline \multirow{3}{*}{ Pair samples test } & \multicolumn{5}{|c|}{ Paired Differences } & \multirow[t]{3}{*}{$t$} & \multirow[t]{3}{*}{$d f$} & \multirow[t]{3}{*}{$\begin{array}{c}\text { Sig. } \\
\text { (2-tailed) }\end{array}$} \\
\hline & \multirow[t]{2}{*}{ Mean } & \multirow[t]{2}{*}{$\begin{array}{c}\text { Std. } \\
\text { deviation }\end{array}$} & \multirow[t]{2}{*}{$\begin{array}{c}\text { Std. } \\
\text { error of } \\
\text { the mean }\end{array}$} & \multicolumn{2}{|c|}{$\begin{array}{l}95 \% \text { confidence } \\
\text { interval of the } \\
\text { difference }\end{array}$} & & & \\
\hline & & & & Lower & Upper & & & \\
\hline ChemSketch & 47.4 & 21.3 & 1.9 & 45.1 & 49.7 & 53.9 & 322 & 0.00 \\
\hline $\begin{array}{c}\text { Software for the creation } \\
\text { of quizzes/LMS }\end{array}$ & 45.7 & 21.5 & 1.2 & 43.3 & 55.6 & 48.1 & 322 & 0.00 \\
\hline $\begin{array}{l}\text { Software for the creation } \\
\text { of interactive tasks (PSs) }\end{array}$ & 47.7 & 21.1 & 1.4 & 44.9 & 50.5 & 33.6 & 219 & 0.00 \\
\hline $\begin{array}{c}\text { E-learning educational } \\
\text { LMS environments (SSs) }\end{array}$ & 41.4 & 22.0 & 2.8 & 37.1 & 45.7 & 19.1 & 102 & 0.00 \\
\hline $\begin{array}{c}\text { Work with interactive } \\
\text { whiteboards }\end{array}$ & 36.7 & 23.3 & 1.3 & 33.6 & 66.3 & 38.7 & 322 & 0.00 \\
\hline
\end{tabular}

PSs - primary schools, SSs - secondary schools

\section{Comprehensive educational environments of the Planet Knowledge [78]}

It is an educational portal currently available to all teachers in Slovakia, containing more than 35,000 interactive educational objects. Teachers are offered several on-line tools for simple search of documents, preparation of teaching materials for their lessons, creation of assignments and homework for students, including relevant review tools. Educational materials are the Slovak version of the Universal Curriculum product by the Young Digital Planet [79]. Chemistry teachers may use more than 2,800 digital educational objects (models, animations, simulations, interactive tests, and exercises) grouped into topic units and individual topics. 
Despite the fact that teachers participating in the course were only enabled to work with a limited version of the Planet Knowledge educational portal with an incomplete database and limited functions, as much as $16.5 \%$ of Chemistry teachers assessed this environment as the most usable digital teaching aid in their pedagogical experience. As the greatest benefit, Chemistry teachers reported the interconnection of the provided educational content with the requirements defined by the national curriculum.

\section{Lesson models supported by digital teaching aids}

Didactically prepared examples of selected Chemistry curriculum topics taught at primary and secondary schools represent the largest part of the prepared teaching materials. They include model examples, prepared by the team of experts, of using available digital technologies in various forms (group education, project-based learning, individual work, etc.) and stages of education (motivation, exposure, consolidation, diagnostics), based on the TPACK model. Each example consists of several alternative procedures to be used when making the Chemistry topics accessible. The importance of experiments and the preference for inquiry-based learning methods are stressed. Students are required to be capable of correct interpretation of data, graphs, and tables, capable of collaboration, discussion, and drawing conclusions.

From the Chemistry teachers' point of view, practical examples of methodology for the appropriate use of software applications and electronic educational environments in Chemistry teaching represented part of the course that is most usable for their pedagogical practice. As much as $36.6 \%$ of them appreciated model examples of topic preparation with the suggestions for appropriate and age-adequate procedures of using digital technologies in the Chemistry curriculum. If we consider this large group, while including the teachers who reported as the most valuable and most usable in the practice the didactically prepared materials related to the preparation and execution of education projects, as well as teachers who appreciated the most the presented examples of using interactive whiteboards in Chemistry teaching, the number of course participants, for whom the methodology materials and didactic manuals, presented during the course, were the most beneficial out of the entire course agenda, exceeds a half $(55.6 \%)$ of all project participants.

\section{Overall evaluation of the second part of Module 3, focused on the ICT integration into Chemistry teaching}

A detailed analysis of answers provided by course participants teaching Chemistry indicates a high degree of satisfaction with the teaching materials prepared by experts and with the agenda of Module 3. Software applications and electronic educational environments that represented the basis of the digital content of the course for Chemistry teachers were evaluated exceptionally positively by $55 \%$ of teachers (Table 9). Only $3.1 \%$ of teachers were not able to formulate their answers to the question regarding the digital technology most usable in the real teaching practice. Upon a more detailed analysis of their answers to other items, we observed that the course (the total quality and the contents of the course) received very positive feedback by more than half of them. Moreover, other $3.7 \%$ of teachers regard all the solutions presented during the course as excellently usable in their teaching practice.

Very positive opinions on the quality of Module 3 were also confirmed by the statistical analysis of answers provided by the participants to the second open question (Table 10). The question on which components of the Module 3 agenda are regarded as 
unusable in the real teaching practice was answered by $31.3 \%$ of Chemistry teachers by claiming that everything they had become familiar with during the course was usable in practice. $16.4 \%$ of Chemistry teachers stated they do not know, and $12.1 \%$ of them did not provide any answer. However, a more detailed analysis of questionnaires showed again that almost 2/3 of Chemistry teachers who did not provide any answer, or those who stated they do not know, reported in other items high values for the degree of satisfaction with the course content, or regarded absolutely everything as usable in the real teaching practice.

Table 9

Percentage of answers provided by chemistry teachers to the open question: Which parts of the course agenda in

Module 3 do you regard as the most positive for the application to the real teaching practice

\begin{tabular}{|c|c|c|}
\hline & Count & Column [\%] \\
\hline Examples of methodology for appropriate use of digital technologies in Chemistry teaching & 118 & 36.6 \\
\hline Chemical graphics software (ChemSketch) & 75 & 23.6 \\
\hline Planet Knowledge educational environment & 53 & 16.5 \\
\hline Educational projects and project-based learning & 33 & 10.2 \\
\hline Answer not provided & 27 & 8.4 \\
\hline Dxamples of using interactive whiteboards in Chemistry teaching & 25 & 7.8 \\
\hline Educational software & 16 & 4.9 \\
\hline Eisualisation of a chemical experiment, virtual laboratory & 16 & 4.9 \\
\hline Eethods and ways of grading the students & 14 & 4.3 \\
\hline I do not know & 12 & 3.7 \\
\hline E-learning environments (LMS Claroline, LMS Moodle) & 11 & 3.4 \\
\hline Development of key competencies & 10 & 3.1 \\
\hline Interactive tasks, educational tests and exercises & 9 & 2.8 \\
\hline Other (frequency less than 4) & 9 & 2.8 \\
\hline & 5 & 1.6 \\
\hline
\end{tabular}

Table 10

Frequency of answers provided by chemistry teachers to the open question: Which parts of the course agenda in module 3 do you regard as unusable in the real teaching practice

\begin{tabular}{|c|c|c|}
\hline & Count & Column [\%] \\
\hline Everything is usable in practice & 101 & 31.3 \\
\hline Computer-assisted experiments and digital measuring systems (Coach, Vernier) & 69 & 21.5 \\
\hline I do not know & 53 & 16.4 \\
\hline No answer & 39 & 12.1 \\
\hline Dependence on a school's technical equipment & 23 & 7.1 \\
\hline Cxamples of using interactive whiteboards in Chemistry teaching & 6 & 1.9 \\
\hline E-learning environments (LMS Claroline, LMS Moodle) & 5 & 1.5 \\
\hline Educational projects and project-based learning & 5 & 1.5 \\
\hline Other (frequency less than 3) & 3 & 0.9 \\
\hline
\end{tabular}

The last open question was examining the opinions among Chemistry teachers on items absent in the course content. The largest group of teachers did not provide any answer to this question $(41.2 \%)$ or they stated that it did not lack anything, or that everything was sufficient and beneficial for them (27.9\%). Another large group of Chemistry teachers $(16.7 \%)$ were not able to provide any answer to this question. Also in this case, these three groups consisted mostly of teachers who expressed in previous questions their high satisfaction with the course. Almost $7 \%(6.8 \%)$ of teachers would appreciate other, 
unspecified examples of lessons, ideas for laboratory works, interesting experiments, more detailed manuals and examples of using digital teaching aids in Chemistry teaching.

\section{Conclusion and implications for practice}

On the basis of our findings, we can state that the successful integration of digital technology into Chemistry teaching requires not only building the technological infrastructure, but also methodological support in form of courses for teachers aimed at increasing their competences in efficient use of ICT in the teaching process and strengthening their confidence in their own efficacy related to the their ability to integrate new technologies in particular lessons. The course based on the TPACK framework, containing specific examples of teaching activities with incorporated technologies, was highly appreciated by the teachers. In particular, examples of methodology for appropriate application of digital technology to a particular Chemistry topic, based on the TPACK model, were regarded by the teachers as the most beneficial, in terms of the real teaching practice.

As the second most beneficial, in terms of practice, the teachers reported the methodologies for the use of freely accessible chemical graphics software in the teaching process. By contrast, as the least usable in the teaching practice they reported the computerassisted scientific experiments, with the reported reason being the absence of microcomputer-based laboratories in schools. In accordance with authors $[11,80,81]$, we can thus state that the level of confidence and the intensity of using digital technologies are also affected by a teacher's personal approach to digital technologies.

Similarly positive self-assessment results were also observed in the assessment of their skills to work with the technology as such, as well as their ability to use such technology meaningfully in the teaching process. On the basis of our findings, we can thus state that the course brought a positive shift in the teachers' confidence in technology and in their own competency to use the technology efficiently in Chemistry teaching.

Participating teachers highly appreciated not only the quality, contents, and overall benefit of individual course modules, but also instructors' work. Principal investigators and performers of the project managed to hire and gradually train excellent instructors, mainly from among the teachers whose expertise, professional approach and competency to assist in the execution of a demanding course agenda were reflected in the excellent assessment of their work. The success of the course was based on the coursebooks prepared by the team of experts, as well as continuously provided supporting didactic materials and methodologies for appropriate and meaningful application of innovative approaches and forms of education, supported by digital technologies.

It showed that teachers negatively evaluated the lack of time for practicing the acquired skills in work with selected technologies and more extensive discussions on their own ideas regarding the ICT implementation in particular topics. It is thus necessary to organise systematic trainings for teachers, providing enough time for the acquisition of the required knowledge and subsequent implementation of technology in their own teaching areas. Similarly, teachers made certain reservations with regard to the execution of the course in training centres. More successful integration of technology into the teaching process probably requires that the trainings are performed directly in schools, where teachers have the possibility to discuss particular transformation of their school, classroom, and teaching process with their colleagues and school management. On the other hand, 
trainings organised as described above would eliminate the development of the cooperation between schools and teachers on the regional level.

The national project aimed at the teaching process modernisation has offered to Chemistry teachers, for the first time in the recent history of Slovakia, a course primarily focused on their subject specialisation and practical use of the acquired knowledge, skills, and habits of working with digital teaching aids. We can assume that this was the very reason of the extraordinary success of the course and interest among majority of teachers in continuation with similar courses and in paying more attention to digital technology and electronic teaching aids, for which this course did not provide enough time, or which were created during the course.

\section{References}

[1] Cox MJ. 2 Motivating Pupils through the Use of ICT. In: Leask M, Pachler N. editors. Learning to Teach using ICT in the Secondary School: A Companion to School Experience. Abingdon: Routledge; 2002. ISBN: 978-0-415-51652-5.

[2] Hennessy S. Graphing investigations using portable (palmtop) technology. J Comput Assist Learn. 2000;16(3):243-258. DOI: 10.1046/j.1365-2729.2000.00136.x.

[3] JeetKaur R, Sharma S. Managing students' attitude towards science through computer assisted instruction. Int Index Refer Res J. 2013;4(40):79-81.

[4] Owusu KA, Monney KA, Appiah, JY, Wilmot EM. Effects of computer-assisted instruction on performance of senior high school biology students in Ghana. Comput Educat. 2010;55(2):904-910. DOI: 10.1016/j.compedu.2010.04.001.

[5] Passey D, Rogers C, Machell J, McHugh G, Allaway D. The motivational effect of ICT on pupils. Lancaster: Department of Educational Research. Lancaster University; 2004. http://portaldoprofessor.mec.gov.br/ storage/materiais/0000012854.pdf.

[6] Pernaa J, Aksela M. Chemistry teachers' and students' perceptions of practical work through different ICT learning environments. Problems of Education in the 21st Century. 2009;16:80-88. http://www.scientiasocialis.lt/pec/files/pdf/vol16/80-88.Pernaa_Vol.16.pdf

[7] Rau P-LP, Gao Q, Wu L-M. Using mobile communication technology in high school education: Motivation, pressure, and learning performance. Comput Educat. 2008;50(1):1-22. DOI: 10.1016/j.compedu.2006.03.008.

[8] Basturk R. The effectiveness of computer-assisted instruction in teaching introductory statistics. J Educat Technol Soc. 2005;8(2):170-178. http://www.ifets.info/journals/8_2/16.pdf.

[9] Çepni S, Taş E, Köse S. The effects of computer-assisted material on student' cognitive levels, misconceptions and attitudes towards science. Comput Educat. 2006;46(2):192-205. DOI: 10.1016/j.compedu.2004.07.008.

[10] Cheng Y-H, Cheng J-T, Chen D-J. The effect of multimedia computer assisted instruction and learning style on learning achievement. WSEAS Transactions Informat Sci Applicat. 2012;9(1):24-35. https://pdfs.semanticscholar.org/fb21/da5db19d486967751f620a8c04069b63c156.pdf.

[11] Cox MJ, Preston C, Cox C. What factors support or prevent teachers from using ICT in the primary classroom. Paper presented at the British Educational Research Association Annual Conference. University of Sussex at Brighton. September 2-5 1999. https://www.leeds.ac.uk/educol/ Retrieved documents/00001304.htm.

[12] Higgins S, Xiao Z, Katsipataki M. The impact of digital technology on learning: A summary for the education endowment foundation. Durham, UK: Education Endowment Foundation and Durham University; 2012. https://educationendowmentfoundation.org.uk/public/files/Publications/The_Impact_of_ Digital_Technologies_on_Learning_(2012).pdf

[13] Keengwe J, Onchwari G, Wachira P. The use of computer tools to support meaningful learning. Associat Advancem Comput In Educat J. 2008;16(1):77-92. http://citeseerx.ist.psu.edu/viewdoc/ download?doi=10.1.1.597.7776\&rep=rep1\&type=pdf.

[14] Liao YKC. Effects of hypermedia on students' achievement: a meta-analysis. J Educat Multimed Hypermed. 1999;8(3):255-277. http://c31.uni-ldenburg.de/cde/media/readings/liao.pdf.

[15] Sun K, Lin Y, Yu CH. A study on learning effect among different learning styles in a Web-based lab of science for elementary school students. Comput Educat. 2008;50(4):1411-1422. DOI: 10.1016/j.compedu.2007.01.003. 
[16] Williamson VM, Abraham MR. The effects of computer animation on the particulate mental models of college Chemistry students. J Res Sci Teach. 1995;32(5):521-534. DOI: 10.1002/tea.3660320508.

[17] Jimoyiannis A. Designing and implementing an integrated technological pedagogical science knowledge framework for science teachers professional development. Comput Educat. 2010;55(3):1259-1269. DOI: 10.1016/j.compedu.2010.05.022.

[18] Polly D, Mims C, Shepherd CE, Inan F. Evidence of impact: Transforming teacher education with preparing tomorrow's teachers to teach with technology (PT3) grants. Teaching Teacher Educat. 2010;26(4):863-870. DOI: $10.1016 /$ j.tate.2009.10.024.

[19] Blonder R, Jonatan M, Bar-Dov Z, Benny N, Rap S, Sakhnini S. Can you tube it? Providing chemistry teachers with technological tools and enhancing their self-efficacy beliefs. Chem Educat Res Practic. 2013;14(3):269-285. DOI: 10.1039/C3RP00001J.

[20] Mishra P, Koehler MJ. Technological pedagogical content knowledge: A framework for teacher knowledge. Teachers College Record. 2006;108(6):1017-1054. DOI: 10.1111/j.1467-9620.2006.00684.x.

[21] So H, Kim B. Learning about problem based learning: Student teachers integrating technology, pedagogy and content knowledge. Austral J Educat Technol. 2009;25(1):101-116. DOI: 10.14742/ajet.1183.

[22] Doering A, Hughes J, Huffman D. Preservice teachers: Are we thinking with technology? J Res Technol Educat. 2003;35(3):342-361. DOI: 10.1080/15391523.2003.10782390.

[23] Brand GA. What research says: Training teachers for using technology. J Staff Develop. 1997;19(1);1-9. http://citeseerx.ist.psu.edu/viewdoc/download?doi=10.1.1.460.2632\&rep=rep1\&type=pdf.

[24] Lee D. Factors influencing the success of computer skills learning among in-service teachers. British J Educat Technol. 1997;28(2):139-141. DOI: 10.1111/1467-8535.00018.

[25] Pina A, Harris B. Increasing teachers' confidence in using computers for education. Paper presented at the Annual Meeting of the Arizona Educational Research Organisation (Tucson, AZ, November 1993). https://files.eric.ed.gov/fulltext/ED365648.pdf.

[26] Koehler MJ, Mishra P. What happens when teachers design educational technology? The development of technological pedagogical content knowledge. J Educat Comput Res. 2005;32(2):131-152. DOI: 10.2190/0EW7-01WB-BKHL-QDYV.

[27] Preston C, Cox M, Cox K. Teachers as innovators: an evaluation of the motivation of teachers to use Information and Communications Technology. South Croydon: MirandaNet; 2000. ISBN 1-871-984-09-2.

[28] Veen W. The role of beliefs in the use of information technology: implications for teacher education, or teaching the right thing at the right time. J Inform Technol Teach Educat. 1993;2(2):139-153. DOI: 10.1080/0962029930020203.

[29] Celik V, Yesilyurt E. Attitudes to technology, perceived computer self-efficacy and computer anxiety as predictors of computer supported education. Comput Educat. 2013;60(1):148-158. DOI: 10.1016/j.compedu.2012.06.008.

[30] Van Acker F, van Buuren H, Kreijns K, Vermeulen M. Why teachers use digital learning materials: The role of self-efficacy, subjective norm and attitude. Educat Informat Technol. 2013;18(3):495-514. DOI: 10.1007/s10639-011-9181-9.

[31] Sang G, Valcke M, van Braak J, Tondeur J. Student teachers' thinking processes and ICT integration: Predictors of prospective teaching behaviors with educational technology. Comput Educat. 2010;54(1):103-112. DOI: 10.1016/j.compedu.2009.07.010.

[32] Ross JA, Hogaboam-Gray A, Hannay L. Predictors of teachers' confidence in their ability to implement computer-based instruction. J Educat Comput Res. 1999;21(1):75-97. DOI: 10.2190/CGXF-YYJE-47KQ-MFA1.

[33] Koehler MJ, Mishra P, Yahya K. Tracing the development of teacher knowledge in a design seminar: integrating content, pedagogy and technology. Comput Educat. 2007;49(3):740-762. DOI: 10.1016/j.compedu.2005.11.012.

[34] Niess ML. Preparing teachers to teach science and mathematics with technology: Developing a technology pedagogical content knowledge. Teaching Teacher Educat. 2005;21(5):509-523. DOI: 10.1016/j.tate.2005.03.006.

[35] Albion P. Self-Efficacy Beliefs as an Indicator of Teachers' Preparedness for Teaching with Technology. In: 10th Int Conf Soc Information Technol Teacher Educat (SITE 1999), 1602-1608. Associat Advancement Computing Educat (AACE). https://eprints.usq.edu.au/6973/1/Albion_SITE_1999_AV.pdf.

[36] Koehler MJ, Mishra P. What is technological pedagogical content nowledge? Contemp Issues Technol Teacher Educat. 2009;9(1):60-70. http://www.citejournal.org/volume-9/issue-1-09/general/what-istechnological-pedagogicalcontent-knowledge.

[37] Shulman LS. Those who understand: knowledge growth in teaching. Educat Res. 1986;15(2):4-14. http://www.fisica.uniud.it/URDF/masterDidSciUD/materiali/pdf/Shulman_1986.pdf. 
[38] Voogt J, Fisser P, Pareja Roblin N, Tondeur J, van Braak J. Technological pedagogical content knowledge - a review of the literature. J Comput Assist Learn. 2012;29(2):109-121. DOI: 10.1111/j.1365-2729.2012.00487.x.

[39] Ay Y, Karadağ, E, Acat MB. The Technological Pedagogical Content Knowledge - practical (TPACKPractical) model: Examination of its validity in the Turkish culture via structural equation modeling. Comput Educat. 2015;88:97-108. DOI: 10.1016/j.compedu.2015.04.017.

[40] Hammond TC, Manfra MM. Giving, prompting, making: aligning technology and pedagogy within TPACK for social studies instruction. Contemp Issues Technol Teacher Educat. 2009;9(2):160-185. http://www.citejournal.org/volume-9/issue-2-09/social-studies/givingprompting-making-aligning-technology-and-pedagogy-within-tpack-for-social-studies-instruction.

[41] Koh JHL, Chai ChS. Teacher clusters and their perceptions of technological pedagogical content knowledge (TPACK) development through ICT lesson design. Comput Educat. 2014;70:222-232. DOI: 10.1016/j.compedu.2013.08.017.

[42] Koehler MJ, Mishra P. Introducing TPCK. Handbook of Technological Pedagogical Content Knowledge (TPCK) for Educators. 2008;3-29. ISBN: 978-0805863550.

[43] McCrory R. Science, Technology, and Teaching: The Topic-specific Challenges of TPCK in Science. In AACTE Committee on Innovation and Technology, editor. Handbook of Technological Pedagogical Content Knowledge (TPCK) for Educators. New York: Routledge; 2008. ISBN 978-1317639763.

[44] Niess ML. Preparing teachers to teach science and mathematics with technology: Developing a technology pedagogical content knowledge. Teach Teacher Educat. 2005;21(5):509-523. DOI: 10.1016/j.tate.2005.03.006.

[45] Jen TH, Yeh YF, Hsu YS, Wu HK, Chen KM. Science teachers' TPACK-Practical: Standard-setting using an evidence-based approach. Comput Educat. 2016;95:45-62. DOI: 10.1016/j.compedu.2015.12.009.

[46] Oster-Levinz A, Klieger A. Online tasks as a tool to promote teachers' expertise within the Technological Pedagogical Content Knowledge (TPACK). Procedia-Social Behavioral Sci. 2010;2(2):354-358. DOI: 10.1016/j.sbspro.2010.03.024.

[47] Chai CS, Koh JHL, Tsai CC. A Review of Technological Pedagogical Content Knowledge. Educat Technol Soci. 2013;16(2):31-51. http://citeseerx.ist.psu.edu/viewdoc/download?doi=10.1.1.299.6205\&rep=rep1\& type $=$ pdf.

[48] Jen TH, Yeh YF, Hsu YS, Wu HK, Chen KM. Science teachers' TPACK-Practical: Standard-setting using an evidence-based approach. Comput Educat. 2016;95:45-62. DOI: 10.1016/j.compedu.2015.12.009.

[49] Yeh Y, Hsu Y, Wu H, Hwang F, Lin T. Developing and validating technological pedagogical content knowledge-practical (TPACK-practical) through the Delphi survey technique. British J Educat Technol. 2013;45(4):707-722. DOI: 10.1111/bjet.12078.

[50] Angeli Ch, Valanides N. Epistemological and methodological issues for the conceptualization, development, and assessment of ICT-TPCK: Advances in technological pedagogical content knowledge (TPCK). Comput Educat. 2009;51:154-168. DOI: 10.1016/j.compedu.2008.07.006.

[51] Lee M-H, Tsai Ch-Ch. Exploring teachers' perceived self efficacy and technological pedagogical content knowledge with respect to educational use of the World Wide Web. Instruction Sci. 2010;38(1):1-21. DOI: 10.1007/s11251-008-9075-4.

[52] Yurdakul IK, Odabasi HF, Kilicer K, Coklar AN, Birinci G, Kurt AA. The development, validity and reliability of TPACK-deep: A technological pedagogical content knowledge scale. Comput Educat. 2012;58(3):964-977. DOI: 10.1016/j.compedu.2011.10.012.

[53] Jang SJ, Chen KC. From PCK to TPACK: Developing a transformative model for pre-service science teachers. J Sci Educat Technol. 2010;19(6):553-564. DOI: 10.1007/s10956-010-9222-y.

[54] Koehler MJ, Mishra P, Kereluik K, Shin TS, Graham CR. The technological pedagogical content knowledge framework. In: Handbook of Research on Educational Communications and Technology. New York: Springer; 2014. DOI: 10.1007/978-1-4614-3185-5_9.

[55] Jimoyiannis A. Developing a technological pedagogical content knowledge framework for science education: Implications of a teacher trainers' preparation program. Proc Informing Sci IT Educat Conf (InSITE). 2010;567-607. http://proceedings.informingscience.org/InSITE2010/InSITE10p597607Jimoyiannis867.pdf.

[56] Engida T. ICT-enhanced Teacher Development Model. Addis Ababa: UNESCO-IICBA. 2011;29. https://www.researchgate.net/profile/Temechegn_Engida/publication/275245938_ICT-enhanced_Teacher_ Development_Model/links/553610410cf20ea35f10fa9b/ICT-enhanced-Teacher-Development-Model.pdf.

[57] Engida T. Chemistry teacher professional development using the technological pedagogical content knowledge (TPACK) framework. Afr J Chem Educat. 2014;4(3):2-21. ISSN 2227-5835. https://www.ajol.info/index.php/ajce/article/view/104084/94193. 
[58] Guzey SS, Roehrig GH. Teaching science with technology: Case studies of science teachers' development of technology, pedagogy, and content knowledge. Contemp Issues Technol Teaching Educat. 2009;9(1):25-45. http://www.citejournal.org/volume-9/issue-1-09/science/teaching-science-with-technology-case-studies-ofscience-teachersdevelopment-of-technology-pedagogy-and-content-knowledge.

[59] Jang SJ, Tsai MF. Exploring the TPACK of Taiwanese elementary mathematics and science teachers with respect to use of interactive whiteboards. Comput Educat. 2012;59(2):327-338. DOI: 10.1016/j.compedu.2012.02.003.

[60] Jang SJ, Tsai MF. Exploring the TPACK of Taiwanese secondary school science teachers using a new contextualized TPACK model. Australasian J Educat Technol. 2013;29(4):566-580. DOI: 10.14742/ajet.282.

[61] Lin TC, Tsai CC, Chai CS, Lee MH. Identifying science teachers' perceptions of technological pedagogical and content knowledge (TPACK). J Sci Educat Technol. 2013;22(3):325-336. DOI: 10.1007/s10956-012-9396-6.

[62] Bell L, Juersivich N, Hammond TC, Bell RL. The TPACK of Dynamic Representations. Educational Technology, Teacher Knowledge, and Classroom Impact: A Research Handbook on Frameworks and Approaches. 2012;103-135. DOI: 10.4018/978-1-4666-4502-8.ch067.

[63] Hechter R, Phyfe L. Using online videos in the science methods classroom as context for developing preservice teachers' awareness of the TPACK components. Proc Soc Informat Technol Teacher Educat Inter Conf. 2010;3841-3848. https://www.learntechlib.org/p/33979/.

[64] Jang SJ. Integrating the interactive whiteboard and peer coaching to develop the TPACK of secondary science teachers. Comput Educat. 2010;55(4):1744-1751. DOI: 10.1016/j.compedu.2010.07.020.

[65] Khan S. New pedagogies on teaching science with computer simulations. J Sci Educat Technol. 2011;20(3):215-232. DOI: 10.1007/s10956-010-9247-2.

[66] Maeng JL, Mulvey BK, Smetana LK, Bell RL. Preservice teachers' TPACK: Using technology to support inquiry instruction. J Sci Educat Technol. 2013;22(6):838-857. DOI: 10.1007/s10956-013-9434-z.

[67] Smetana LK, Bell RL. Computer simulations to support science instruction and learning: A critical review of the literature. Int J Sci Educat. 2012;34(9):1337-1370. DOI: 10.1080/09500693.2011.605182.

[68] Karolčík Š, Čipková E. Digital technologies in the education process from the Slovak teachers' perspective. Int Multidiscipl Sci Conf Social Sci Arts. SGEM Conf Psychol Psychiatry, Sociol Healthcare, Educat. Albena, Bulgaria: 2014;681-692.

[69] EUR-Lex - 32006H0962 - EN - EUR-Lex. Recommendation of the European parliament and of the council of 18 December 2006on key competences for lifelong learning (2006/962/EC). http://eur-lex.europa.eu/eli/reco/2006/962/oj.

[70] ISTE Standards Teachers. International Society for Technology in Education. 2008. http://www.iste.org/docs/pdfs/20-14_ISTE_Standards-T_PDF.pdf.

[71] Aksela M, Lundell J. Computer-based molecular modelling: Finnish school teachers' experiences and views. Chem Educat Res Pract. 2008;9(4,):301-308. DOI: 10.1039/B818464J.

[72] Chiu MH, Wu HK. The roles of multimedia in the teaching and learning of the triplet relationship in Chemistry. Multiple Representat Chem Educat. 2009;251-283. DOI: 10.1007/978-1-4020-8872-8_12.

[73] Gabel D. Improving teaching and learning through Chemistry education research: A look to the future. J Chem Educat. 1999;76(4):548-554. DOI: 10.1021/ed076p548.

[74] Leask M, Pachler N. editors. Learning to Teach using ICT in the Secondary School: A Companion to School Experience. 3rd Edition. Routledge. 2014;262. ISBN 978-0-415-51652-5.

[75] Osborne J, Dillon J. Good Practice In Science Teaching: What Research Has To Say. Berkshire: McGraw-Hill Education; 2010; 352. ISBN 978-0-33-523858-3. https://channayousif.files.wordpress.com/ 2011/06/good-practice-in-science-teaching-what-research-has-to-say.pdf.

[76] Webb M. Impact of IT on science education. In: International Handbook of Information Technology in Primary and Secondary Education. New York: Springer; 2008;133-148. DOI: 10.1007/978-0-387-73315-9.

[77] ACD/ChemSketch for Academic and Personal Use: ACD/Labs.com. http://www.acdlabs.com/ resources/freeware/chemsketch/.

[78] Naučteviac.sk - Vzdelávací portal pre moderných učitel'ov. http://www.naucteviac.sk/.

[79] Young Digital Planet. http://www.ydp.eu/.

[80] Karolčík Š, Čipková E, Kinchin I. Teacher attitudes to professional development of proficiency in the classroom application of digital technologies. Int Educat Stud. 2016;9(4):9-19. DOI: 10.5539/ies.v9n4p9.

[81] Tschannen-Moran M, Woolfolk-Hoy A, Hoy WK. Teacher efficacy: its meaning and measure. Rev Educat Res. 1998;68(2):202-248. DOI: 10.3102/00346543068002202. 


\title{
POSTAWY NAUCZYCIELI CHEMII WOBEC ZWIECKSANIA KOMPETENCJI OSOBISTYCH W STOSOWANIU PRAKTYKI TIK
}

\begin{abstract}
Abstrakt: Analizie poddano opinie i postawy nauczycieli chemii biorących udział w narodowym projekcie „Modernizacja Procesu Edukacyjnego w Szkołach Podstawowych i Ponadpodstawowych”. Część badawcza opracowania składa się $\mathrm{z}$ analizy wyników, które prezentują ogólne zadowolenie uczestników kursu z poziomu zawodowego, trudności i treści zaprojektowanego modelu nauczania opartego na TPACK (Technological Pedagogical Content Knowledge) oraz samoocenę nabytych umiejętności i wiedzy w zakresie pracy z poszczególnymi aplikacjami programowymi i sprzętowymi. Wyniki wskazują, że kurs oparty o ramy TPACK i obejmujący konkretne przykłady działań dydaktycznych wspieranych przez wykorzystanie technologii został wysoko oceniony przez nauczycieli. Przykłady metodologii właściwego wykorzystania technologii cyfrowych w konkretnym temacie nauczania chemii z wykorzystaniem modelu TPACK zostały ocenione przez nauczycieli jako najkorzystniejsze pod względem faktycznej praktyki dydaktycznej. Badania potwierdziły, że nauczyciele oczekują technologii edukacyjnych wraz z wysokiej jakości wskazówkami metodycznymi oraz konkretnymi przykładami działań dydaktycznych wiążących się z odpowiednim i efektywnym wykorzystaniem danej technologii cyfrowej w procesie nauczania.
\end{abstract}

Słowa kluczowe: TIK w nauczaniu chemii, metody nauczania, technologie edukacyjne, kursy dla nauczycieli, nauczanie chemii, technologie informacyjne i komunikacyjne 